\title{
Ladders of Authority, Status, Responsibility and Ideology: Toward a Typology of Hierarchy
}

\author{
A. Georges L. Romme ${ }^{1, *}$
}

1 Eindhoven University of Technology, department of Industrial Engineering \& Innovation Sciences

* Correspondence: a.g.l.romme@tue.nl; Tel.: +31 402472170

\begin{abstract}
The notion of hierarchy is widely used in many academic disciplines but is also rather ambiguous, because there are many ways to define it. In this review paper, I explore which notions of hierarchy are being used in the field of management and organization studies. Four distinct types of hierarchy are identified: a ladder of formal decision-making authority, a ladder of achieved status, a self-organized ladder of responsibility, and an ideology-based ladder. A social mechanismbased perspective serves to define and distinguish these four types. Subsequently, the typology is further developed by comparing the four hierarchy types in terms of their tacit/explicitness, (in)transitivity, and behavior- versus cognition-centeredness. This review paper contributes to the literature by dissecting the general metaphor of hierarchy into four different constructs and their social mechanisms, which serves to create a typology of the various ways in which hierarchy is being used in the domain of organization and management. This typology can inform future research drawing on any type of hierarchy, also in other domains.
\end{abstract}

Keywords: hierarchy; management; organization; formal authority; social mechanism; ideology; self-organization; responsibility; status; typology; literature review

\section{Introduction}

The notion of hierarchy is widely used but is also rather ambiguous, because highly different interpretations of hierarchy exist. For example, in software development the notion of hierarchy refers to different levels of abstraction - such as those in an (e.g., Android) operating system [1]. In companies and other organizations, hierarchy is often defined as a sequence of levels of formal decision-making authority [2-4]. Another interpretation available in the literature is hierarchy as a ladder of ideology, in which people establish themselves as legitimate leaders of their organization by invoking some (e.g., religious, spiritual or political) idea to legitimize the relationship between higher or lower levels [5]. And yet another notion has been developed in the field of organization design and organizational agility, in which hierarchy is conceived as a requisite structure that emerges in a self-organized manner from operational activities [6-9].

The ambiguous and multi-faceted nature of hierarchy has been mainly theorized in terms of the distinction between formal and informal hierarchy $[10,11]$. However, this formal-informal dichotomy does not cover the entire landscape of how hierarchy has been conceptualized and instantiated [e.g., 5-7]. Therefore, the purpose of this review is to map the various ways in which hierarchy is defined in organization and management studies, to develop a typology of hierarchy. Four types of hierarchy are identified:

- ladder of formal decision-making authority levels, also known as formal hierarchy [2,3];

- ladder of achieved status levels (e.g., arising from seniority or expertise), also known as informal hierarchy [12,13];

- ladder of responsibility levels, arising from self-organizing initiatives throughout the organization [6,7]; and 
- ladder of ideology that draws on a set of shared beliefs to justify the relationships between higher and lower levels [5].

Subsequently, I further develop this typology by comparing the four types on several key dimensions. This paper contributes to the literature by dissecting the general metaphor of hierarchy into four fundamentally different constructs.

\section{Review Scope and Approach}

Earlier reviews $[10,11]$ in this area served to define the notions of formal and informal hierarchy and explore their complementarity. These reviews and related studies [e.g., 14] suggest that formal and informal hierarchy tend to complement each other, and thereby are likely to make the organizational structure more stable but also less responsive to major external changes. As argued in the first section, these prior reviews have not mapped the entire landscape of hierarchy constructs, and therefore a more inclusive taxonomy and typology is developed in this article. The scope of this literature review is limited to the domain of organization and management studies. Moreover, I focus on studies published in double blind-reviewed journals as well as widely cited monographs and books in this domain [e.g., 15,16], only adding sources from adjacent disciplines like sociology and law when the results of (reading) the initial set of sources pointed at the need to consult these additional publications.

Accordingly, this review in the domain of organization and management covers hierarchy notions used at the micro-level (e.g., individual and group behavior) and macrolevel (e.g., strategy, organization design) as well as exploring various peripheral literatures - such as the literature on requisite structure [6].

In defining and comparing the various types of hierarchy, I adopt a mechanism-based perspective $[17,18]$. In this respect, social mechanisms such as the 'social construction of status' and the 'self-organizing process of responsibility' serve to explain why a particular type of hierarchy arises and/or prevails [19]. The notion of social mechanism has been previously used to bridge and synthesize insights from different philosophical perspectives and research streams [e.g., 20,21], because it is relatively agnostic about the nature of social action and can, therefore, steer a path between positivist, narrative and functional perspectives [17]. This agnostic lens is important here, because the notion of hierarchy is used in fundamentally different paradigms and discourses in organization and management studies - for example [2] and [22-24].

\section{Main Findings: Four Types of Hierarchy}

\subsection{Hierarchy as Ladder of Authority}

A common conception of hierarchy is in terms of a sequence of formal authority levels, that is, the authority to make decisions [3,4,25-28]. Following Max Weber [29], a ladder of authority involves the vertical formal integration of official positions within a single organizational structure, in which each position is under the supervision and control of a higher one. Similarly, Dumont refers to "a ladder of command in which the lower rungs are encompassed in the higher ones in regular succession" [16] (p. 65). This results in a ladder that systematically differentiates authority, for example from CEO to shopfloor worker.

A key assumption underlying this construct of hierarchy is that formal authority is, at least initially, concentrated at the top levels of the ladder [7], who can delegate specific decision authorities to lower levels in view of the bounded rationality of, and limits to, managerial attention $[3,4]$. This concentration of authority at the top of the hierarchy often arises from the legal ownership and constitution of the organization [7]; the key constitutional principle here being that people at the top level, as rightful holders of authority, have the right to dictate targets and/or behaviors and are entitled to be obeyed. In this respect, many organizations have an elaborate constitution that contains the fundamental principles and bylaws regarding positions, decision domains, and 
related issues. For example, the chain of formal authority in family-owned companies starts at the level of the owners, that is, the family members that have shares [7].

In many publicly traded companies, ownership and control have become largely separated [30,31]. As a result, the ladder of authority in these companies has become rather complex, in terms of the formal authority arising from the shareholders' legal ownership, the CEO controlling the company on a day-to-day basis, and non-executive directors engaging in supervisory activities [32-35].

\subsection{Hierarchy as Ladder of Status}

Another widely used meaning of hierarchy is in terms of informal or unofficial mechanisms to rank people [13,22]. These informal mechanisms are highly persondependent, involving for example social norms and values, verbal or non-verbal attitudes and behaviors, and guidelines for communication [10]. At a more fundamental level, the source of these informal hierarchies are differences in personal status, other than those arising from formal authority. Status is one's social standing or professional position, relative to those of others [36] or "the respect one has in the eyes of others" [11] (p. 351). In anthropology and sociology, this notion of status is also known as 'achieved status', the social position that is earned, instead of being ascribed [37,38]. The underlying mechanism is social stratification, a social mechanism that draws on shared cultural beliefs that can make status differences between people appear natural and fair $[39,40]$.

Ladders of status are frequently observed in empirical work [e.g., 12,13,22]. For instance, He and Huang [22] studied how the deference for one another gives rise to a status hierarchy within a firm's board of directors. Another example is Dwertmann and Boehm's study [12] of how status drives the quality of the relationship between supervisor and subordinate. Overall, any ladder of status is socially constructed, which makes it fundamentally different from the ladder of authority that (largely) arises from the organization's legal structure. This also implies a status ladder is much more fluid and adaptive than its authority-driven counterpart.

While social comparison can to some extent also take place between (people from) different units and departments within an organization [41], the person-dependent nature of status implies that ladders of status primarily arise within the group of people one interacts with on a daily basis - be it a team, work unit, department, or network of people $[12,13,22,36,42]$.

\subsection{Hierarchy as Ladder of Responsibility}

In the literature on organization design and organizational agility, hierarchy is conceived as a requisite structure that emerges in a self-organized manner from operational activities [6-8]. A key source here is Jaques [6,43], who argued that hierarchy is the only effective organizational mechanism that can employ large numbers of people and yet preserve unambiguous accountability for the work they do. Jaques' notion of hierarchy is part of his broader perspective on requisite organization, defined as the organizational roles and connections that make the entire system operate efficiently as required by the nature of human nature and the enhancement of mutual trust [6]. The notion of requisite hierarchy has informed the development of new organizational forms like Holacracy $[8,44]$, which involves a system of self-organizing circles that structure roles and work processes [7,9]. In designing holacracy, Robertson [44] assumed that this hierarchical network of circles, at any given point in time, has an (ideal) requisite structure that 'wants' to emerge.

More specifically, the key mechanism driving hierarchy in these agile and/or holacratic forms of organizing is that agents at all levels self-organize their responsibility, that is, exercise 'real' rather than formal authority $[7,45]$. In this respect, responsibility is an expression of self-restraint and intrinsic obligation [46-48]. Other examples of self- 
organized ladders of responsibility have been observed in (the early stages of) worker cooperatives in which hierarchy is created in a bottom up manner [49] and in so-called sociocratic organizations that draw on a circular hierarchy of double-linked circles [50].

\subsection{Hierarchy as Ladder of Ideology}

The fourth conception of hierarchy identified in the literature is the so-called ladder of ideology, in which people establish themselves as legitimate leaders of their organization by invoking some (e.g., religious, spiritual or political) idea to legitimize the hierarchical relationship between higher or lower levels [5,51-53]. Ideological hierarchies have a long history, for example in the form of the administrative hierarchies headed by pharaohs in ancient Egypt or those headed by kings in medieval Europe. The main legitimacy of any pharaoh or king arose from the strong belief in the idea that the pharaoh/king acts as the intermediary between the gods and the people, and thus deputizes for the gods [53]. A similar example is the hierarchy prevailing until today in the Balinese community, which is strongly connected to the rice cycle that is believed to constitute a hierarchical relationship between gods and humans, both of whom must play their parts to secure a good crop; the same ideology also legitimizes the hierarchical relationship between high castes and low castes in Bali [52].

Ladders of ideology continue to exist in many organizational settings, for example in the form of ladders fueled by prevailing values and beliefs among members of the organization about how the world should operate [54,55]. For example, Brummans et al. [5] identified a ladder of ideology in their study of how leaders in a Buddhist humanitarian organization create and sustain hierarchical relationships with subordinates. They observed that these leaders invoke a spiritual entity in their daily interactions and use this invocation to direct their organization and establish a shared sense of compassion and wisdom [5].

More generally speaking, a ladder of ideology is a sense-making mechanism for coordinating work, one that creates and sustains a set of collective beliefs and values that provide standardized interpretations of the environment and thus reduce uncertainty [56]. From a scholarly point of view, any ideology is a black box involving a cluster of (mostly implicit) values and imperatives that serve to 'bracket' the ways in which members of the incumbent organization should think and operate [57]. Compared to the other hierarchy types, the ideology ladder is thus much more tacit and obscure.

\subsection{Overview}

Table 1 provides an overview of the four types of hierarchy identified in the literature. As such, these four types incorporate the well-known distinction between (formal) authority-based and status-based (informal) hierarchy, but also go beyond it by defining two additional types of hierarchy.

Notably, the outline of each hierarchy type in Table 1 refers to its archetypical form. In practice, the hierarchy prevailing in many organizations tends to involve mixed instantiations of these pure types. For example, several studies have demonstrated how 'visionary' leaders (on top of the authority ladder) select other managers based on their fit with a core ideology as well as thoroughly indoctrinate employees into this ideology, to create a strong cognitive framework that drives employee behavior $[54,58]$ or how top management's ideology affects the way subordinates make sense of key problems and opportunities $[59,60]$. In these organizations, the instantiated hierarchy therefore appears to involve both authority-based and ideology-driven ladders. Other examples are how worker cooperatives over time tend to extend and integrate their initial ladder of responsibility with ladders of authority and status $[49,61]$. 
Table 1. An overview of four types of hierarchy.

\begin{tabular}{|c|c|c|c|c|}
\hline & Ladder of authority & Ladder of status & Ladder of responsibility & Ladder of ideology \\
\hline Definition & $\begin{array}{l}\text { Sequence of people (as- } \\
\text { signed to roles) with for- } \\
\text { mal authority to make de- } \\
\text { cisions }\end{array}$ & $\begin{array}{l}\text { Sequence of levels con- } \\
\text { structed by people in } \\
\text { terms of perceived dif- } \\
\text { ferences in e.g. seniority, } \\
\text { age, experience or exper- } \\
\text { tise }\end{array}$ & $\begin{array}{c}\text { Sequence of decision/task } \\
\text { domains to which people } \\
\text { have an intrinsic sense of } \\
\text { obligation and commit- } \\
\text { ment }\end{array}$ & $\begin{array}{l}\text { Sequence of levels in which peo- } \\
\text { ple establish themselves as lead- } \\
\text { ers by invoking an ideology to } \\
\text { justify the hierarchical relation- } \\
\text { ships between higher and lower } \\
\text { levels }\end{array}$ \\
\hline $\begin{array}{l}\text { Core } \\
\text { concept }\end{array}$ & $\begin{array}{l}\text { Authority: the legitimate } \\
\text { power to make decisions }\end{array}$ & $\begin{array}{l}\text { Status: one's relative so- } \\
\text { cial standing or profes- } \\
\text { sional position, that is, } \\
\text { the respect one has in the } \\
\text { eyes of others }\end{array}$ & $\begin{array}{l}\text { Responsibility: the sense of } \\
\text { intrinsic obligation to one- } \\
\text { self, others and/or particu- } \\
\text { lar challenges }\end{array}$ & $\begin{array}{l}\text { Ideology: the prevailing (e.g., reli- } \\
\text { gious, spiritual or political) values } \\
\text { and beliefs regarding about how } \\
\text { the organization should operate }\end{array}$ \\
\hline Mechanism & $\begin{array}{l}\text { Legitimacy of authority, as } \\
\text { it arises from the constitu- } \\
\text { tion (or statutes) of the or- } \\
\text { ganization }\end{array}$ & $\begin{array}{l}\text { Social construction of } \\
\text { status differences }\end{array}$ & $\begin{array}{l}\text { Self-organization of re- } \\
\text { sponsibility, in which indi- } \\
\text { viduals take charge of par- } \\
\text { ticular tasks/challenges at } \\
\text { higher levels of abstraction }\end{array}$ & $\begin{array}{l}\text { Creating, adopting and/or sus- } \\
\text { taining ideology as a collective } \\
\text { sense-making (and thus possibly } \\
\text { indoctrination) process }\end{array}$ \\
\hline Assumptions & $\begin{array}{l}\text { Decision-making authority } \\
\text { is (initially) concentrated } \\
\text { at the top, which may del- } \\
\text { egate authority to lower } \\
\text { levels to reduce (conse- } \\
\text { quences of) information } \\
\text { overload and bounded ra- } \\
\text { tionality }\end{array}$ & $\begin{array}{l}\text { Source of status is } \\
\text { contingent on what } \\
\text { drives respect and } \\
\text { deference for other } \\
\text { people within the (same } \\
\text { unit of the) organization }\end{array}$ & $\begin{array}{l}\text { Responsibility is some- } \\
\text { thing that people 'take' ra- } \\
\text { ther than 'get', in order to } \\
\text { grow and sustain a sub- } \\
\text { stantial level of intrinsic } \\
\text { obligation and commit- } \\
\text { ment }\end{array}$ & $\begin{array}{l}\text { Ideologies influence how people } \\
\text { make sense of their (organiza- } \\
\text { tional) world, by providing } \\
\text { standardized interpretations of } \\
\text { the environment and thereby re- } \\
\text { ducing uncertainty }\end{array}$ \\
\hline
\end{tabular}

\section{Further Development of the Typology}

This section serves to further develop the typology of hierarchy outlined in Table 1. First, I will map these hierarchy types in terms of the tacit/explicitness of the knowledge constituting them. Subsequently, the four types are categorized using two additional dimensions.

Using knowledge theory [62], the four types of hierarchy can be placed on a continuum from fully tacit to fully explicit knowledge (see Figure 1). The ladder of authority is the most explicit form of hierarchy, with written rules and procedures as a defining characteristic $[29,63]$. These written rules originate from the constitution and statutes of the organization, extended via (executive) decisions on lower-level decision domains - communicated via job descriptions, decision logs, meeting minutes and other texts [3]. Such written rules on decision authorities impose normative and behavioral restrictions on subordinates [63], especially in the area of decision-making. In many instances, these rules are followed deliberately and consciously, while in other instances "rule following in organizations occurs unnoticed because rules have been internalized, have become unconscious premises of action, or have been incorporated into firmly established and widely practiced routines and procedures" [63] (p. 9).

At the other end of the continuum in Figure 1, ideology ladders appear to be largely tacit in nature because they draw on so-called collective tacit knowledge [62]. As observed in section 3.4, a ladder of ideology is a sense-making mechanism that creates and sustains a set of collective beliefs and standardized interpretations, which in turn appear to operate (especially for outsiders) as a black box filled with tacit and obscure knowledge [56,57].

Status and responsibility ladders are positioned in the middle of the continuum in Figure 1. A status ladder draws a bit more on somatic knowledge, arising from the properties of individual bodies and brains as physical entities [62], whereas responsibility 
ladders appear to be somewhat more explicit in nature $[8,49,50]$ than their status-based counterparts.

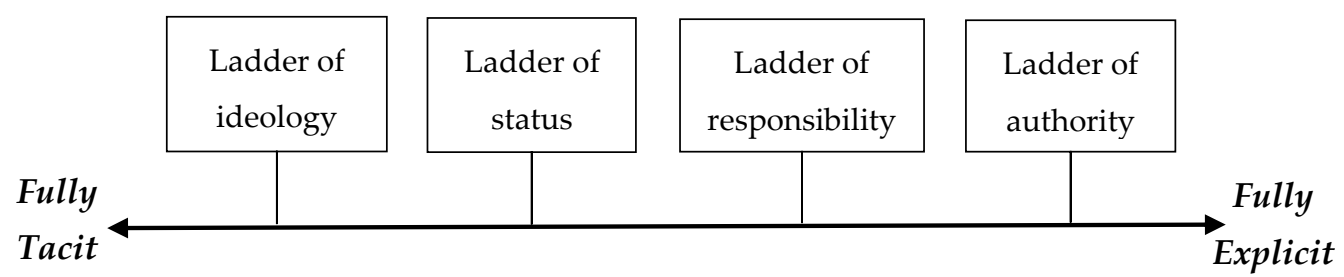

Figure 1. Four types of hierarchy on the tacit-explicit knowledge continuum.

Another way to map the four types of hierarchy draws on the (in)transitive nature of each type as well as its behavior or cognition centeredness (see Figure 2). The notion of transitivity refers to the extent to which the key mechanism (e.g., authority or status) can be delegated and/or transferred from one level to another [7]. In this respect, the authority and ideology ladder both are transitive in nature. That is, formal authority and strong ideology can be relatively easily delegated or cascaded from the top level to various lower levels. As a result, large corporations as well as large religious organizations often operate on rather deep hierarchies.

By contrast, responsibility and status cannot be (easily) delegated or transferred to other people, and these ladders are therefore non-transitive. Accordingly, responsibility and status ladders are unlikely to have more than two layers. For example, when persons $\mathrm{A}$ and $\mathrm{B}$ share the perception that $\mathrm{A}$ has a higher (e.g., experience-driven) status, and B and $C$ both believe $B$ has a higher status, it does not follow that $A$ and $C$ also have a common perception of their relative status. Therefore, any ladder of responsibility or status is likely to have only two levels [cf., 7].

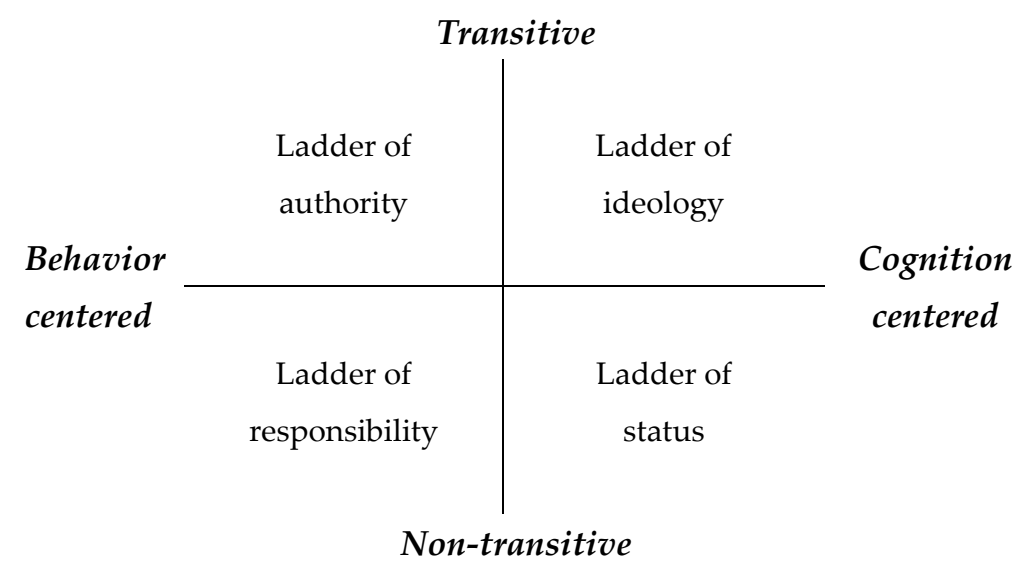

Figure 2. The types of hierarchy categorized in terms of their transitive/non-transitive nature and behavior/cognition centeredness.

The other axis in Figure 2 is the difference between a behavior-centered and cognitioncentered hierarchy. A behavior-centered ladder focuses on actions (to be) taken or constrained. By contrast, a cognition-centered hierarchy focuses on the mental activity required to carry it, including various attentional, judgmental, reasoning, sensory and neural processes [64]. Here, the ladders of authority and responsibility are both largely centered around behavior: the authority-based ladder draws on decision domains, authorization procedures, budget constraints and actual decisions taken [e.g., 3,63] and the ladder of responsibility involves agents seeking higher-level responsibilities and acting accordingly [e.g., 7,65,66]. By contrast, ideology-based and status-based hierarchies are both largely cognition-centered, by either invoking some ideology to legitimize the hierarchical relationship between higher or lower levels [e.g., 5 and 51-53] or drawing on 
shared cultural beliefs regarding status differences [e.g., 12,13,22,38]. The two dimensions together result in the matrix in Figure 2.

\section{Discussion and Conclusion}

Based on a review and synthesis of the various ways in which hierarchy has been defined and used in the field of organization and management, a typology of hierarchy was developed in the two preceding sections. This new typology has major implications for research in the area of organization and management, which thus far draws on a single conception of hierarchy [e.g., 13,41,67,68] or focuses on the interaction between authoritydriven and status-based hierarchy [e.g., 10,11,14]. Here, the broader mechanism-based framework outlined in Table 1 can guide future research efforts in various areas. More specifically, future work in the area of organizational citizenship $[69,70]$, emergent leadership in self-managing teams [71,72], power and empowerment $[73,74]$ and new organizational forms $[75,76]$ can greatly benefit from a more differentiated understanding of the various ways in which hierarchy can be shaped and how different instantiations of hierarchy interact over time. For example, scholars studying new organizational forms can develop theories of the interaction and integration of multiple types of hierarchies outlined in Table 2, also to resolve longstanding disputes on the nature and role of hierarchy in modern organizations [43,77-80].

More importantly, the typology developed in this article serves to clarify the pivotal but highly ambiguous role of the hierarchy construct in management practice as well as research. Herbert Simon [81] developed a generic notion of hierarchy, which can now be dissected in four distinct types. In this respect, the hierarchy notion appears to be rather ambiguous for academics as well as practitioners because the underlying mechanisms of authority, status, ideology and responsibility are often not properly defined or understood.

The multi-faceted nature of hierarchy also reflects the fact that some form of hierarchy exists in human as well as nonhuman primate groups $[11,82,83]$. Hierarchy appears to be functionally adaptive in allowing any kind of group "to achieve the high levels of coordination and cooperation necessary to ensure survival and success" [83] (p. 33). The typology developed in this paper underlines the functional adaptability of hierarchy.

Funding: This research received no external funding.

Informed Consent Statement: Not applicable.

Conflicts of Interest: The author declares no conflict of interest.

\section{References}

1. Gabrielli, M.; Martini, S. Programming Languages: Principles and Paradigms; Springer: London, UK, 2010.

2. Butler, J.C.; Grahovac, J. Learning, imitation, and the use of knowledge: A comparison of markets, hierarchies, and teams. Organ Sci 2012, 23, 1249-1263.

3. Dobrajska, M.; Billinger, S.; Karim, S. Delegation within hierarchies: How information processing and knowledge characteristics influence the allocation of formal and real decision authority. Organ Sci 2015, 26, 687-704.

4. Tirole, J. Hierarchies and bureaucracies: On the role of collusion in organizations. J Law Econ Organ 1986, 2, 181-214.

5. Brummans, B.H.J.M.; Hwang, J.M.; Cheong, P.H. Mindful authoring through invocation: Leaders' constitution of a spiritual organization. Manage Commun Q 2013, 27, 346-372.

6. Jaques, E. Requisite Organization: A Total System for Effective Managerial Organization and Managerial Leadership for the 21st century (2nd ed.); Cason Hall \& Co: Arlington, USA, 1996.

7. Romme, A.G.L. 2019. Climbing up and down the hierarchy of accountability: Implications for organization design. J Organ Des 2019, 8, 20.

8. Robertson, B.J. Holacracy: The New Management System for a Rapidly Changing World; Henry Holt: New York, USA, 2015.

9. Monarth, H. A company without job titles will still have hierarchies. HBR.org digital article, 2014. Available online: https://hbr.org/2014/01/a-company-without-job-titles-will-still-have-hierarchies/

10. Diefenbach, T.; Sillince, J.A.A. Formal and informal hierarchy in different types of organization. Organ Stud 2011, 32, $1515-1537$.

11. Magee, J.C.; Galinsky, A.D. Social hierarchy: The self-reinforcing nature of power and status. Acad Manag Ann 2008, 2, 351-398. 
12. Dwertmann, D.J.G.; Boehm, S.A. Status matters: The asymmetric effects of supervisor-subordinate disability incongruence and climate for inclusion. Acad Manag J 2016, 59, 44-64.

13. Joshi, A.; Knight, A.P. Who defers to whom and why? Dual pathways linking demographic differences and dyadic deference to team effectiveness. Acad Manag J 2015, 58, 59-84.

14. Bunderson, J.S.; Van der Vegt, G.S.; Cantimur, Y.; Rink, F. Different views of hierarchy and why they matter: Hierarchy as inequality or as cascading influence. Acad Manag J 2016, 54, 1119-1139.

15. Ackoff, R.L. Re-creating the Corporation: A Design of Organizations for the 21st Century. Oxford University Press: New York, USA, 1999.

16. Dumont, L. Homo Hierarchicus. University of Chicago Press: Chicago, USA, 1980.

17. Gross, N. A pragmatist theory of social mechanisms. Am Sociol Rev 2009, 74, 358-379.

18. Hedström, P.; Ylikoski, P. Causal mechanisms in the social sciences. Annu Rev Sociol 2010, 36: 49-67.

19. Davis, G.F.; Marquis, C. 2005. Prospects for organization theory in the early twenty-first century: Institutional fields and mechanisms. Organ Sci 2005, 16, 332-343.

20. Anderson, P.J.J.; Blatt, R.; Christianson, M.K.; Grant, A.M.; Marquis, C.; Neuman, E.J.; Sonenshein, S.; Sutcliffe, K.M. Understanding mechanisms in organizational research: Reflections from a collective journey. J Manage Inquiry, 2006, 15, $102-113$.

21. Van Burg, E.; Romme, A.G.L. 2014. Creating the future together: Toward a framework for research synthesis in entrepreneurship. Entrep Theory Pract 2014, 38, 369-397.

22. He, J.; Huang, Z. Board informal hierarchy and firm financial performance: Exploring a tacit structure guiding boardroom interactions. Acad Manag J 2011, 54, 1119-1139.

23. Parker, M. Angelic organization: Hierarchy and the tyranny of heaven. Organ Stud, 2009, 30, 1281-1299.

24. Zhou, Y.M. Designing for complexity: Using divisions and hierarchy to manage complex tasks. Organ Sci 2013, $24,339-355$.

25. Adler, P.S. Market, hierarchy, and trust: The knowledge economy and the future of capitalism. Organ Sci 2001, 12, 215-234.

26. Casson, M. Why are firms hierarchical? Int J Econ Bus 1994, 1, 47-76.

27. Ouchi, W.G.; Price, R.C. Hierarchies, clans, and theory Z: A new perspective on OD. Organ Dyn 1978, 7, $24-44$.

28. Williamson, O.E. Transaction cost economics and organization theory. Ind Corp Chang 1993, 2, 107-156.

29. Weber, M. Wirtschaft und Gesellschaft: Grundriss der verstehenden Soziologie (ed. by A. Ulfig). Zweitausendeins-Verlag: Frankfurt am Main, Germany, 1922/2005.

30. Fama, E.F.; Jensen, M.C. Separation of ownership and control. J Law Econ 1983, 26, 301-326.

31. Kraakman, R.; Armour, J.; Davies, P.; Enriques, L.; Hansmann, H.; Hertig, G.; Hopt, K.; Kanda, H.; Pargendler, M.; Ringe, W.; Rock, E. The Anatomy of Corporate Law: A Comparative and Functional Approach (3 ${ }^{\text {rd }}$ edition). Oxford University Press: Oxford, UK, 2017.

32. Foss, N.J.; Weber, L. Moving opportunism to the back seat: Bounded rationality, costly conflict, and hierarchical forms. Acad Manag Rev 2016, 41, 61-79.

33. Aguilera, R.V.; Crespi-Cladera, R. Global corporate governance: On the relevance of firms' ownership structure. J World Bus 2016, 51, 50-57.

34. Charkham, J.; Simpson, A. Fair Shares: The Future of Shareholder Power and Responsibility. Oxford University Press: Oxford, UK, 1999.

35. Deakin, S. Against shareholder empowerment. In Beyond Shareholder Value: The Reasons and Choices for Corporate Governance Reform; Williamson, J., Driver, C., Kenway, P., Eds.; TUC: London, UK, 2014, pp. 36-40.

36. George, G.; Dahlander, L.; Graffin, S.D.; Sim, S. Reputation and status: Expanding the role of social evaluations in management research. Acad Manag J 2016, 59, 1-13.

37. Bourdieu, P. Distinction: A Social Critique of the Judgment of Taste. Harvard University Press: Cambridge, USA, 1984.

38. Ravlin, E.C.; Thomas, D.C.; Status and stratification processes in organizational life. J Manag 2005, 31, 966-987.

39. Anderson, C.; Hildreth, J.; Howland, L. Is the desire for status a fundamental human motive? A review of the empirical literature. Psychol Bull 2015, 141, 574-601.

40. Saunders, P. (1990) Social Class and Stratification. Routledge: New York, USA, 1990.

41. Baumann, O.; Eggers, J.P.; Stieglitz, N. Colleagues and competitors: How internal social comparisons shape organizational search and adaptation. Adm Sci Q 2019, 64, 275-309.

42. Djurdjevic, E.; Stoverink, A.C.; Klotz, A.C.; Koopman, J.; da Motta Veiga, S.P.; Yam, K.C.; Ting-Ju Chiang, J. Workplace status: The development and validation of a scale. J Appl Psychol 2017, 102, 1124-1147.

43. Jaques, E. In praise of hierarchy. Harv Bus Rev 1990, 68 (1), 127-133.

44. Robertson, B.J. Organization at the leading edge: Introducing Holacracy evolving organization. Integral Leadership Review 2007. Available online: http://integralleadershipreview.com/5328-feature-article-organization-at-the-leading-edge-introducing-holacracy-evolving-organization/

45. Aghion, P.; Tirole, J. Formal and real authority in organizations. Journal of Political Economy 1997, 105, 1-29.

46. Drucker, P.F. Managing in a Time of Great Change. Dutton: New York, USA, 1995.

47. Ansell, C.K. Pragmatist Democracy: Evolutionary Learning as Public Philosophy. Oxford University Press: Oxford, UK, 2011.

48. Early, P.C. Social loafing and collectivism: A comparison of the United States and the People's Republic of China. Adm Sci Q 1989, 34, 565-581.

49. Whyte, W.F.; Whyte, K.K. Making Mondragon ( $2^{\text {nd }}$ edition). ILR Press: New York, USA, 1991. 
50. Romme, A.G.L.; Endenburg, G. Construction principles and design rules in the case of circular design. Organ Sci 2006, 17, 287297.

51. Gelfand, M. Shona Ritual. Juta \& Co: Cape Town, South Africa, 1959.

52. Howe, L. Rice, ideology, and the legitimation of hierarchy in Bali. Man 1991, 26, 445-467.

53. Shaw, G.J. The Pharaoh, Life at Court and on Campaign. Thames \& Hudson: London, UK, 2012.

54. Pettigrew, A.M. On studying organizational cultures. Adm Sci Q 1979, 24, 570-581.

55. Gupta, A.; Briscoe, F.; Hambrick, D.C. Red, blue, and purple firms: Organizational political ideology and corporate social responsibility. Strateg Manag J 2017, 38, 1018-1040.

56. Hirsch, P.M. From ambushes to golden parachutes: Corporate takeovers as an instance of cultural framing and institutional integration. American Journal of Sociology 1986, 91, 800-837.

57. Sartori, G. (1969) Politics, ideology, and belief systems. American Political Science Review 1969, 63, 398-411.

58. Collins, J.C.; Porras, J.I. Built to Last. Harper Business: New York, USA, 1994.

59. Briscoe, F.; Chin, M.K.; Hambrick, D.C. CEO ideology as an element of the corporate opportunity structure for social activists. Acad Manag J 2014, 57, 1786-1809.

60. Carnahan, S.; Greenwood, B.N. Managers' political beliefs and gender inequality among subordinates: Does his ideology matter more than hers? Adm Sci Q 2018, 63, 287-322.

61. Varman, R.; Chakrabarti, M. Contradictions of democracy in a workers' cooperative. Organ Stud 2004, 25, 183-208.

62. Collins, H.M. Tacit and Explicit Knowledge. University of Chicago Press: Chicago, USA, 2010.

63. March, J.G.; Schulz, M.; Zhou, X. The Dynamics of Rules: Change in Written Organizational Codes. Stanford University Press: Stanford, USA, 2000.

64. Gavetti, G. Cognition and hierarchy: Rethinking the microfoundations of capabilities' development. Organ Sci 2005, 16, 599-617.

65. Romme, A.G.L. (1999) Domination, self-determination and circular organizing. Organ Stud 1999, $20,801-832$.

66. Foss, N.J.; Dobrajska, M. (2015) Valve's way: wayward, visionary, or voguish? J Organ Des 2015, 4 (2), 12-15.

67. Brown, A.D.; Kornberger, M.; Clegg, S.; Carter, C. 'Invisible walls' and 'silent hierarchies': A case study of power relations in an architecture firm. Human Relations 2010, 63, 525-549.

68. Ethiraj, S.K.; Levinthal, D.A. Bounded rationality and the search for organizational architecture: An evolutionary perspective on the design of organizations and their evolvability. Adm Sci Q 2004, 49, 404-437.

69. Bolino, M.C.; Hsiung, H.-H.; Harvey, J.; LePine, J.A. “Well, I'm tired of tryin'!” Organizational citizenship behavior and citizenship fatigue. J Appl Psychol 2015, 100, 56-74.

70. Klotz, A.C.; Bolino, M.C.; Song, H.; Stornelli, J. Examining the nature, causes, and consequences of profiles of organizational citizenship behavior. J Organ Behav 2018, 39, 629-647.

71. Gerpott, F.H.; Lehmann-Willenbrock, N.; Voelpel, S.C.; Van Vugt, M. It's not just what is said but also when it's said: A temporal account of verbal behaviors and emergent leadership in self-managed teams. Acad Manag J 2019, 62, 717-738.

72. Carte, T.A.; Chidambaram, L.; Becker, A. Emergent leadership in self-managed virtual teams. Group Decis Negot 2006, 15, 323343.

73. Courpasson, D.; Dany, F.; Clegg, S. Resisters at work: Generating productive resistance in the workplace. Organ Sci 2012, 23, 801819.

74. Hempel, P. S.; Zhang, Z.-X.; Han, Y. Team empowerment and the organizational context: Decentralization and the contrasting effects of formalization. J Manag 2012, 38, 475-501.

75. Gulati, R.; Puranam, P.; Tushman, M. Meta-organization design: Rethinking design in interorganizational and community contexts. Strateg Manag J 2012, 33, 571-586.

76. Puranam, P.; Alexy, O.; Reitzig, M. What's "new" about new forms of organizing? Acad Manag Rev 2014, 39, $162-180$.

77. Romme, G. The big misconceptions holding holacracy back. HBR.org digital article, 2015. Available online: https://hbr.org/2015/09/the-bigmisconceptions-holding-holacracy-back

78. Lee, M.Y.; Edmondson, A.C. Self-managing organizations: Exploring the limits of less-hierarchical organizing. Res Organ Behav 2017, 37, 35-58.

79. Burkus, D. Under New Management: How Leading Organizations are Upending Business as Usual. Houghton Mifflin Harcourt: New York, USA, 2016.

80. Romme, G. The Quest for Professionalism: The Case of Management and Entrepreneurship. Oxford University Press: Oxford, UK, 2016.

81. Simon, H.A. The organization of complex systems. In Hierarchy Theory: The Challenge of Complex Systems; Pattee, H.H., Ed.; George Braziller: New York, USA, 1973, pp. 1-27.

82. Fiske, S.T. Interpersonal stratification: Status, power, and subordination. In Handbook of Social Psychology (5th edition); Fiske S.T., Gilbert D.T., Lindzey G., Eds.; Wiley: New York, USA, 2010, pp. 941-982.

83. Halevy, N.; Chou, E.Y.; Galinsky, A.D. A functional model of hierarchy: Why, how, and when vertical differentiation enhances group performance. Organ Psychol Rev 2011, 1, 32-52. 